\title{
Characteristics of Micro Spatial Patterns, Functions and Meanings of the Towani Tolotang's Traditional House
}

\author{
Husnirrahman Jamaluddin. ${ }^{\text {a,* }}$, Afifah Harisah ${ }^{\mathrm{b}}$, Ria Wikantaric, \\ aDepartment of Architecture, Engineering Faculty, Hasanuddin University, Makassar, Indonesia. Email: husnirrahman.jamal@yahoo.com \\ b Department of Architecture, Engineering Faculty, Hasanuddin University, Makassar, Indonesia. Email: ifahhussein@ yahoo.co.id \\ 'Department of Architecture, Engineering Faculty, Hasanuddin University, Makassar, Indonesia. Email: rwikantaria@gmail.com
}

\begin{abstract}
The architecture of Towani Tolotang's traditional house has characteristics that represents the identity, activities, social and cultural values of the community. The Towani Tolotang people strongly maintain the relationship of togetherness and unity shown by the architecture of traditional houses. This study discussed and examined the characteristics of micro spatial patterns, functions, and meanings of the Towani Tolotang's traditional house. The study was conducted in Amparita Village, Sidrap Regency, South Sulawesi. The discussion on the architecture of the traditional house of Towani Tolotang was carried out by applying the naturalistic phenomenological method. This type of research is qualitative with the process of collecting data through participatory observation, in-depth interviews, and document studies. Data analysis was performed using descriptive qualitative, describing in accordance with the natural situation. The results of the study revealed that there were two spaces in the spatial pattern of Towani Tolotang's traditional house being the characteristics different from Bugis's houses in general. They were tamping and special rooms. The function of the space was similar to the Bugis's house in general, except the two spaces. Tamping was functioned as a place to receive guests with the status of ordinary people, and the special room was used as a place for ritual and taking prayer for the people of Towani Tolotang. Every space in the Towani Tolotang's traditional house has its own meaning, included tamping which means respect for the traditional leader and special room which means the sacred space.
\end{abstract}

Keywords: House function and meaning; micro spatial pattern; Towani tolotang; traditional house

\section{Introduction}

As with other Archipelago ethnics, each ethnic in South Sulawesi has diverse cultural characteristics. Cultural diversity in the Bugis community appears in traditional houses. One of the Bugis community groups that still fosters and maintains the architectural characteristics of their traditional houses is the Towani Tolotang community. There are two groups of Towani Tolotang social strata, namely ordinary people and $U w a$ ' (community leader).

The traditional house of Towani Tolotang has its uniqueness seen in the form of round pillars and rooms with no chairs. So both the house owner and the guest just sit on the floor. Uwa's house (traditional stakeholders) has a large living room because guests usually come in large numbers. The existence of tamping is also seen in the interior of the house, the difference in floor height which distinguishes the social strata or the position of ordinary people and $U w a$ ', the lower floor for ordinary people, and the higher floor for Uwa'.

\footnotetext{
*Corresponding author. Tel.: +6285299999737

BTN Pao-Pao Permai Blok E2 No. 2,
}

Gowa, Sulawesi Selatan
The traditional house of Towani Tolotang still has the shape and characteristics of Bugis's houses in general. But, the uniqueness or identity in detail about Towani Tolotang's traditional house has not been known surely by the community. Not only in its form and function, but also its relation to worldview is not fully understood. Related to this, it can be obtained that the people of Sidrap in general and the Towani Tolotang community themselves do not know the meaning behind the symbols of the architecture of their traditional houses.

The architecture of the Towani Tolotang's traditional house related to social cultural views or values of life has not been specifically discussed by previous researchers. Likewise, studies that discuss traditional houses by looking at their relevance to social patterns, traditions, home space functions and community life values have not been reviewed. On the other hand, it is important to study in order to see the structural relationship between the Towani Tolotang's traditional house and social activities and community values systems. Related to this, the author raised the architecture of the traditional house Towani Tolotang as an object of study. The focus of this study was on three problem statements namely how the micro spatial 
pattern is, how the function is and how the meaning of space in the traditional house of the Towani Tolotang community is in Amparita, Sidrap Regency.

\section{Literature Review}

\subsection{Traditional houses concept}

Traditional houses are further developments from ordinary houses into typical houses such as the king's house, houses of worship and so on. Home is a human work in three important dimensions in life; the house creates an "imaginary space" in a tangible space that can be used, as a place that limits "something" to the world around it, and aims to make humanity the "main part" of the surrounding environment [1].

The cultural change is seen in the changes of behavior and activity. Those then manifest in the physical form of the building. Implicitly, there is a relationship between behavior and the shape of the building in two ways. First, the shape of the building is the physical manifestation of behavior patterns, including desires, motivations and feelings. Second, that if a form has been built, then it will affect behavior and lifestyle [2].

\subsection{Traditional architecture}

According to Amos Rapoport in the book House Form and Culture [2], traditional architecture is an architectural work that grows from popular architecture with all kinds of traditions and optimizes or utilizes local potentials. For example, material, technology and knowledge. Because traditional architecture greatly optimizes the potential or local culture, a building with a traditional concept takes environmental sustainability into account so it is also a sustainable architecture. Traditional architecture was discovered by trial and error by the people themselves.

Rapoport also added that architectural work was created not only to carry the symbol or to be used solely as a place to live but it contains deeper meaning than just as a shelter for humans. In traditional society, architecture is always associated with religious things. Religious matters, something that is considered sacred are the main considerations in the preparation of architectural patterns.

\subsection{Spaces}

A field that is developed will turn into space. Space in a three-dimensional concept has length, width and height. Space consists of points (where several fields meet), lines (where the two fields intersect) and fields (as boundaries of space), so that shapes are created. Form is the main feature that shows a space, determined by the appearance and relationship between fields that explain the boundaries of space. A space can be solid (space has mass), or empty space (space is inside or limited by fields). The visual characteristics are (1) appearance (the result of a certain configuration of surfaces and sides of a shape), (2) dimensions (determining proportions and scale), (3) color (affecting the visual weight of a shape), (4) texture (affects the quality of reflection of light on the surface of the shape), (5) position (relative position of a shape to the environment), (6) orientation (determines the direction of view), (7) visual inertia (degree of concentration and stability of a form; inertia of a shape depends on the geometry and its orientation relative to the base plane). These visual characteristics will always be influenced by the perspective or perspective of the observer, the distance of the observer to the shape, the lighting conditions, and the visual environment that surrounds the shape [3].

\subsection{Spatial pattern}

Architecture not only takes the form and appearance of a building, but also includes the space where each activity takes place. The need for public and private spaces is one of the determinants in the formation of spatial patterns or structures.

Space occurs because of the relationship between humans and the objects they see, and the relationship is not only determined by sight, but is also influenced by smell, hearing, and touch. Most human activities occur outdoors. Outer space occurs by limiting nature, separated from nature by giving a "frame", so it is not nature itself that can expand infinitely. Outer space also means as a man-made outer environment with a specific purpose, it can be said of a space as part of nature. The part that is limited by the "frame" when we look inward, then the space inside the "frame" is referred to as positive space, in which there are functions, intentions and human will. Outer space is limited by two areas, namely floors and walls or space that occurs using two limiting elements [4].

\subsection{Function}

In architecture-interior, use and image become very important in creating the atmosphere of space. Building in the form of inanimate objects does not mean soulless. The house built is a human home. Therefore it is something that is actually always being breathed on by human life, character, lust and ideals. The house represents the image of the builder [5].

In the context of use which refers to profit, the use of pleasure, comfort and security, the main function of a house is as a residential space that accommodates domestic activities. In essence, architectural-interior works are valued for giving satisfaction to social and personal needs, used in a number of ways that are useful or functioning for human life [6].

\subsection{Meaning}

In relation to the taxonomy of meaning, C.K. Ogden and I.A. Richards, in The Meaning of Meaning, identified at least 23 'meanings' of the word 'meaning'. There are fundamental differences in the use of the concept 'meaning' in various scientific fields. The meaning in aesthetic context is different from the meaning of meaning in symbolic context. Phenomenology uses the word meaning in terms of 'essence' or 'essence' of something; psychoanalysis uses the word meaning to explain 'will' and 'desire'; then aesthetics use it to explain the specific emotional levels involved in a work; hermeneutics sees meaning as a product of the interpretation of a text; symbolic relates to the unique relations between an object and the 'world'; and semiotics uses the term meaning to explain the 'concept' (signified) behind the sign [7]. 


\section{Research Methods}

\subsection{Type of research}

In this qualitative study, the role of researchers was as a key instrument in collecting and interpreting data. Data collection tools used direct observation, interviews and document studies. Triangulation with inductive methods was used to check the validity and reliability of the data. The results of qualitative research emphasize more on meaning than generalization [8].

Research on the architecture of Towani Tolotang's traditional house, especially micro spatial patterns, functions and their meaning are relevant with qualitative research because they meet the characteristics of it. This was indicated in the in-depth data disclosure through interviews, observations and document reviews of what the informants were doing, arranging and functioning the space in the houses of the Towani Tolotang community.

The method used in this research is the naturalistic phenomenology method. Phenomenology is a thought that not only looks at everything from the outside but tries to explore the meaning of what is behind the phenomenon [9].

The phenomenological method seeks to illustrate the meaning of the life experiences of several individuals regarding the concept of the phenomena they experience, where adherents of phenomenology try to study the structure of consciousness in individual experiences.

Based on the above understanding, with this research, the researcher intended to obtain all information regarding the traditional houses of the Towani Tolotang community, especially the micro spatial patterns, functions and reasons. All facts, desires, prejudices, which were obtained by interacting directly with informants namely the Towani Tolotang community who were then used in analyzing the phenomena that occurred. This research was conducted in May until July 2019.

\subsection{Research objects}

The object of research is something that is of concern in a study, the object of this study is the target in research to get answers and solutions to problems that occur. As for Sugiyono explained the understanding of the object of research is a scientific target to obtain data with specific goals and uses about something objective, valid and reliable about a thing (certain variables) [10].

The object under study was the traditional house of Towani Tolotang which was the residence of the Tolotang community leader called Uwa'. This research focused on the concept of micro-spatial pattern of functions and meaning of traditional houses. In the Towani Tolotang community there are two classes of social strata, namely ordinary people and $U w a '$ (community leader). The Towani Tolotang community has several Uwa', but in this study the researchers purposely selected eight Uwa's houses that had the most influence on the community as samples. Those Uwa' has many adherents and was considered an elder by the Towani Tolotang community. Of the eight Uwa's houses to be investigated, only five Uwa' were willing to provide information about their traditional house using interview and documentation methods.

\subsection{Data collection techniques}

a. Observation, the observation technique used was unstructured observation studies. At the beginning of a study, it is possible that the observer does not have a clear idea of certain aspects that require focus. In observing events as they are can also be part of the plan in many qualitative studies (qualitative study). In that case, the observer will note practically everything that is observed. Such studies are unstructured observational studies.

b. The interview is part of a qualitative method. In this study the authors used in-depth interview techniques. In-depth interview is the process of obtaining information for research purposes by way of question and answer face to face between the interviewer and the respondent or interviewee, with or without using interview guides where the interviewer and the informant are involved in relative social life long time ago [11]. The special feature of this in-depth interview is its involvement in the life of the key person.

c. Document study is a data collection method that is not addressed directly to the research subject. Document study is a type of data collection that examines various kinds of documents that are useful for analysis material. Some data was obtained from the Amparita Village office and the Religious Affairs Office of Amparita, as well as the community leader of Towani Tolotang.

\subsection{Data analysis techniques}

a. Data Reduction, was the process of selecting, focusing on simplifying, extracting, and transforming rough data arising from written records in the field. Where after researchers obtained data, feasibility should first be assessed by selecting which data was really needed in this study.

b. Display (Data Presentation), the presentation of data was limited as a collection of arranged information that was adjusted and clarified to facilitate researchers in mastering data and not immersed in a pile of data.

c. Conclusions was the final stage in the research process to give meaning to the data that had been analyzed. The data processing process began with structuring field data (raw data), then reduced in the form of unification and data categorization.

\subsection{Data validity check}

The validity of the data is the truth of the data can be trusted because of the consistency of the procedure and the neutrality of its findings and decisions [12]. The validity tests of the data seem carried out is the credibility test (degree of trust), then using the inspection technique that is triangulation.

In this study, researchers used triangulation techniques with sources and methods. In the technique of triangulation with sources, the researcher compared the results of interviews obtained from each source or research 
informant: the community, customary officials, or 'panrita bola' of traditional house of Towani Tolotang as a comparison to check the truth of the information obtained. In addition, researchers also checked the degree of trust through triangulation techniques with methods, namely by checking the results of research with different data collection techniques: interviews, observations, and document studies so that the degree of data confidence can be valid.

\section{Discussion}

\subsection{Specific review of research locations}

The Towani Tolotang community has a traditional leader or stakeholder, namely $U w a$ '. Based on the results of data collection at the study site, information was obtained that some of Uwa's houses 'which had the most influence on the community, namely $U w a$ ' which had many adherents and were considered as elders by the Towani Tolotang community. These Uwa' were chosen based on their status in the society which has a high position in the sense that they are descendants of the previous Uwa', then have the courage to act, are honest, just, wise and authoritative, and are chosen based on the decision of the custom assembly.

In this study, the researchers were directed to eight of Uwa's houses which had the most influence on the community, but of the eight $U w a$ ' only five were willing to share information using interview and documentation methods. The five Uwa' are Uwa' Tadang, Uwa' Eja, Uwa' Jappi, Uwa' Sikki, and Uwa' Cina'.

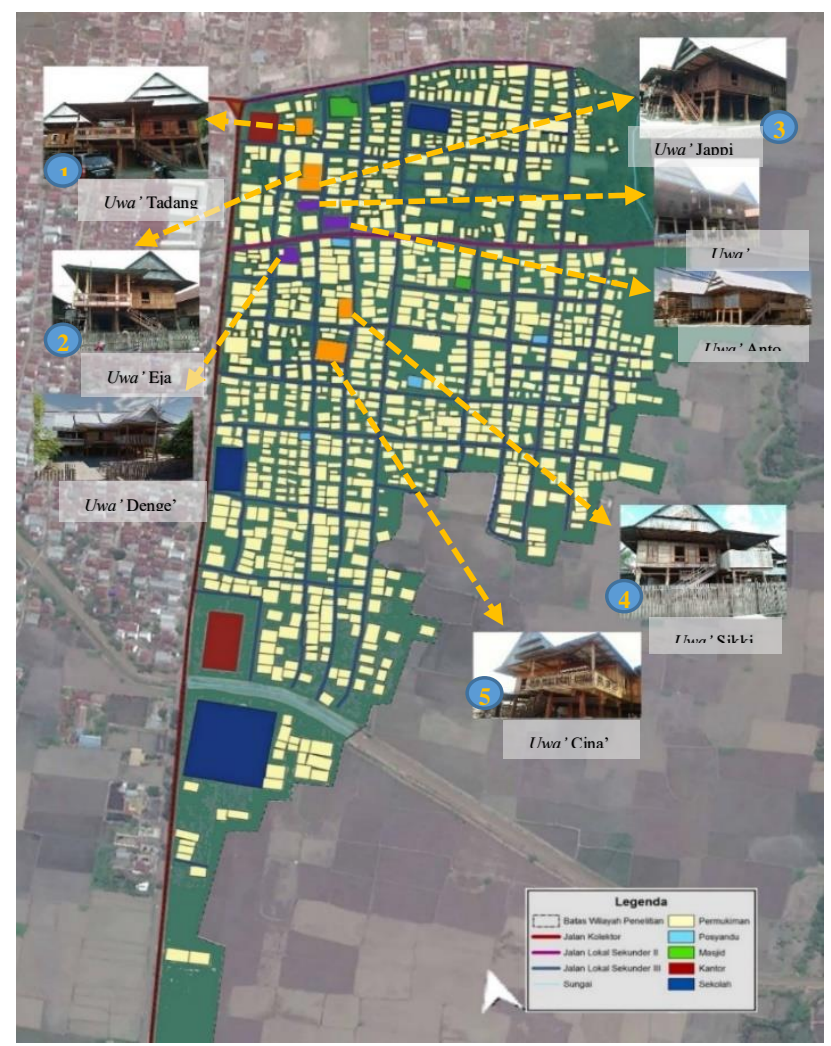

Figure 1. Map of $U w a$ ' Point House in Amparita
The a map of Uwa's house point in Amparita Village, can be seen in Fig. 1. The Uwa's House which is willing to be interviewed marked in orange, while the Uwa's House which is not willing marked in purple.

Based on observations at the research location, only five $U w a$ ' were willing to be interviewed and to provide information about the Towani Tolotang's traditional house. Their houses were then used as samples to get the characteristics of the micro spatial pattern, function and meaning of the Towani Tolotang's traditional house.

\section{a. Uwa' Tadang (Sample 1)}

Figure 2 is a view and space in the house of Uwa' Tadang. Figure 3 is the vertical relationship pattern of Uwa' Tadang's house, which starts from the awa bola (under the house), then goes up to the ale bola (the body of the house), then goes up to the rakkeang (attic).
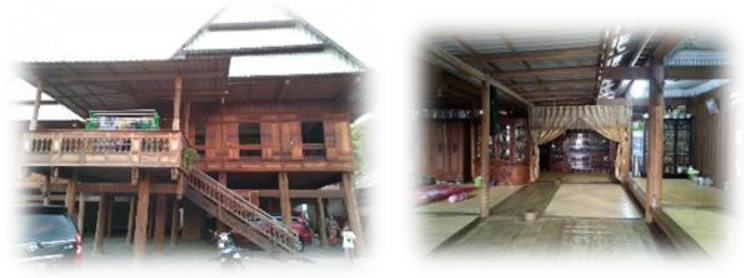

Figure 2. Uwa' Tadang's House

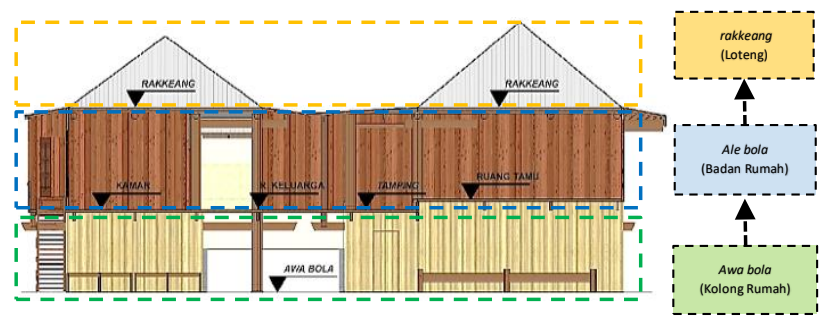

Figure 3. Vertical Relationship Pattern of $U w a$ ' Tadang's House

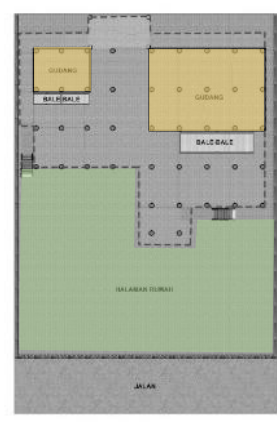

(a)
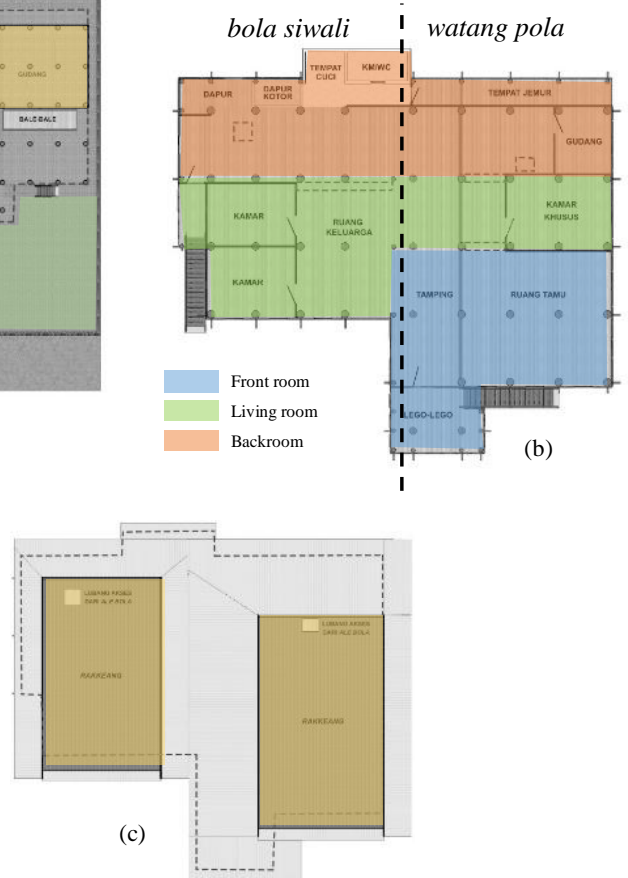

Figure 4. Horizontal Relations Pattern of $U w a$ ' Tadang's House (a) awa bola, (b) ale bola, (c) rakkeang 
Shown in Fig. 4, part (a) is the spatial pattern of $U w a$ ' Tadang's house, where there is a yard area marked in green, then underneath the house is a warehouse for farming equipment and other tools marked in orange.

Part (b) is the zoning and spatial pattern of Uwa' Tadang's house. Uwa' Tadang's House consists of watang pola and bola siwali. In the house there are three zones, the first of which is blue front, consisting of lego-lego as a place to wait for guests, living room and tamping, where the position of tamping is lower than the room guests are intended as a tribute to the customary holders, because ordinary people can only sit on the Tamping. Then the green color is the middle part, consisting of the bedroom, family room and special room as a place of ritual and pray, where the special room is placed right on the possi bola (home center), the position of the bola is one of the sacred and considered sacred parts of the house, so this room is also considered sacred. Then the red color is the back, consisting of a warehouse, kitchen, bathroom/toilet, washing place, and a clothesline.

Part (c) is the layout pattern of rakkeang (attic) of the house of Uwa' Tadang's used for storing harvests. The house is marked in orange.

\section{b. Uwa' Eja (Sample 2)}

Figure 5 shows a view and space in the house of $U w a$, Eja. Figure 6 shows is the vertical relationship pattern of Uwa' Eja's house, which is the same as the previous Uwa's house which was preceded by awa bola (under the house), then up to the ale bola (body of the house), then up to rakkeang (attic).

In Fig. 7, part (a) is the spatial pattern of Uwa' Eja's house, where there is a yard area marked in green, then underneath the house there is a warehouse for farming equipment and other tools marked with orange color.

Part (b) is the zoning and spatial pattern of Uwa' Eja's house. The Uwa' Eja's house only consists of watang pola and has no bola siwali, in the house there are three zones, the first of which is the blue color in the front, consisting of lego-lego as a place to wait for guests, living rooms and tamping, where tamping positions are more lower than the living room is intended as a tribute to the customary holder, because ordinary people can only sit on tamping. Then the green color is the middle part consisting of a special room as a place of ritual and praying, where the special room is placed right on the possi bola (center of the house), the possi bola is one of the sacred parts of the house, so this room is also considered sacred. Then the red color is the back, consisting of the family room, storeroom, kitchen, bathroom/ toilet, washing area, and clothesline.

Section (c) is the spatial layout pattern (attic) of Uwa' Eja's house which is used to store the harvest. In that house the shelves are marked in orange.

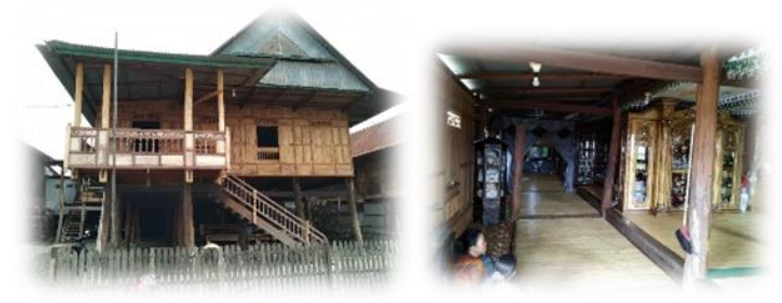

Figure 5. Uwa' Eja's House

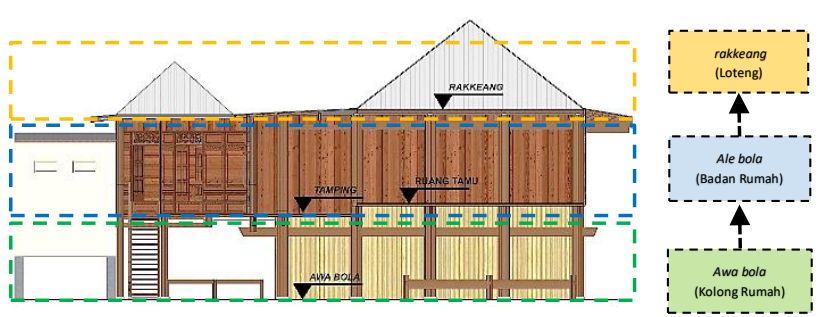

Figure 6. Vertical Relationship Pattern of $U w a$ ' Eja's House

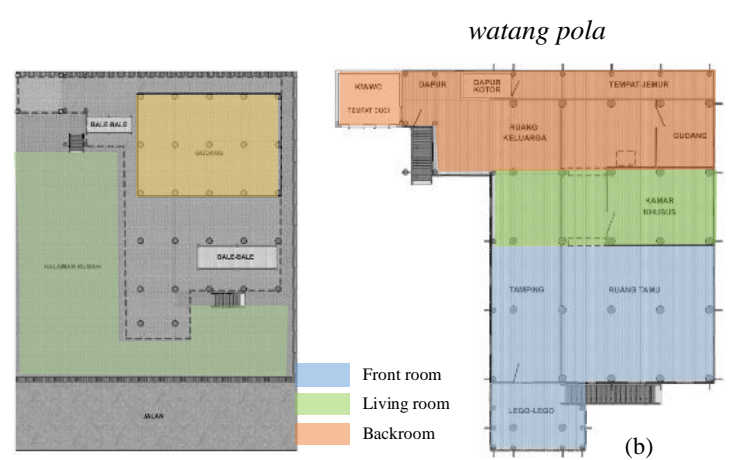

(a)

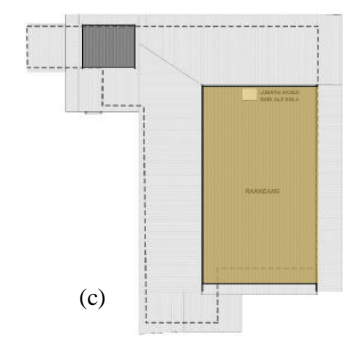

Figure 7. Horizontal Relations Pattern of Uwa' Eja's House (a) awa bola, (b) ale bola, (c) rakkeang

\section{c. Uwa' Jappi (Sample 3)}

Figure 8 is a view and space in the house of $U w a$ ' Jappi. Figure 9 is a vertical relationship pattern of Uwa' Jappi's house, which is the same as the previous Uwa's house which was preceded by awa bola (under the house), then up to the ale ale (home body), then up to rakkeang (attic).

In Fig. 10 above part (a) is the spatial pattern of Uwa' Jappi's house, where there is a yard area marked in green, then underneath the house is a storage room for farming equipment and other tools marked in orange.

Section (b) is the zoning and spatial pattern of Uwa' Jappi's house. Uwa' Jappi's house consists of watang pola and bola siwali, in the house there are three zones, the first of which is blue as the front area, consisting of lego-lego as a place to wait for guests, living room and tamping, where the position of tamping is lower than the living room is intended as a tribute to the customary holders, because ordinary people can only sit on the tamping. Then the green color is the middle part consisting of a special room as a place of ritual and praying, where the special room is placed right on the possi bola (center of the house), the possi bola is one of the sacred parts of the house, so this room is also considered sacred. Then the red color is the back, consisting of the family room, storeroom, kitchen, bathroom / WC, washing area, and clothesline. 


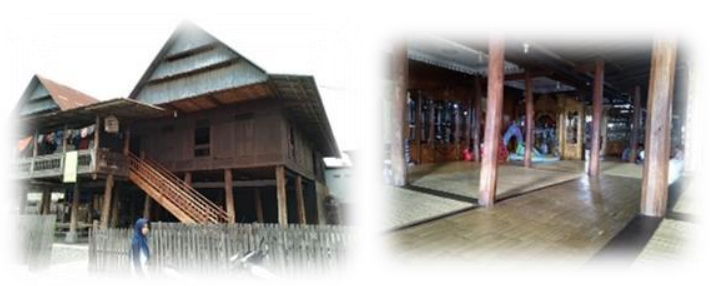

Figure 8. Uwa' Jappi’s House

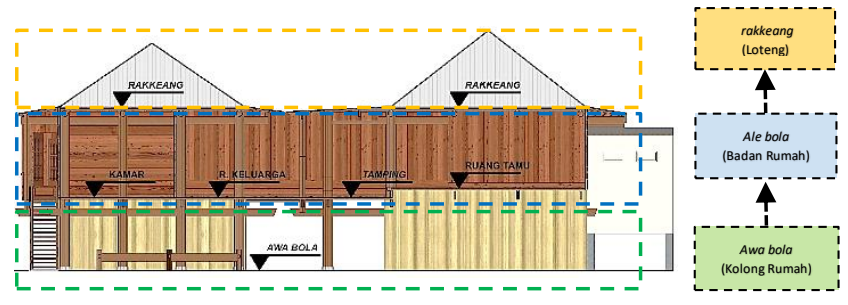

Figure 9. Vertical Relationship Pattern of Uwa' Jappi’s House

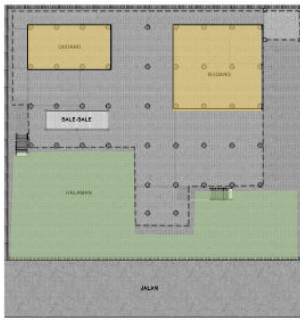

(a)
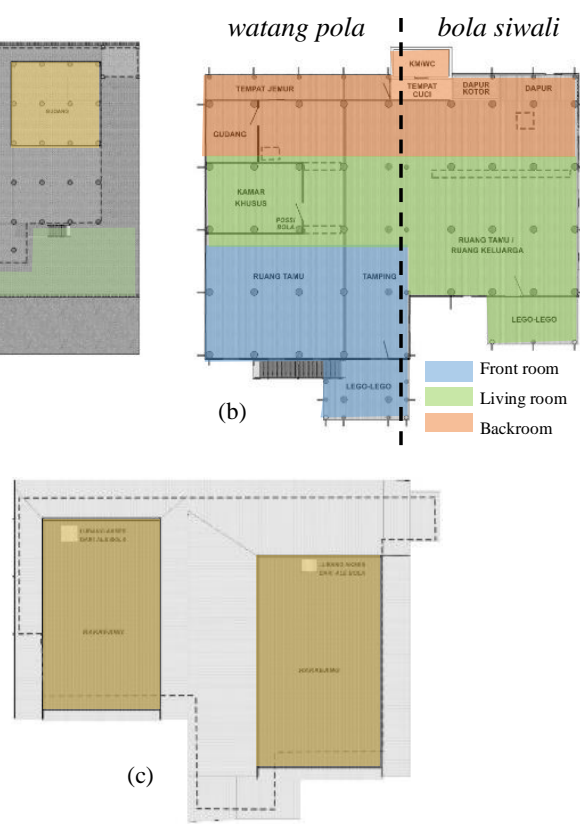

Figure 10. Horizontal Relations Pattern of Uwa' Jappi's House (a) awa bola, (b) ale bola, (c) rakkeang

Section (c) is the spatial pattern of the Rakkeang (attic) of Uwa' Jappi's house which is used to store the harvest. The house is marked in orange.

\section{d. Uwa' Sikki (Sample 4)}

Figure 11 is a view and space in the house of $U w a$ ' Sikki. Figure 12 is the vertical relationship pattern of $U w a$ ' Sikki's house, which starts from the awa bola (under the house), then goes to the ale bola (body of the house), then goes up to the rakkeang (attic).
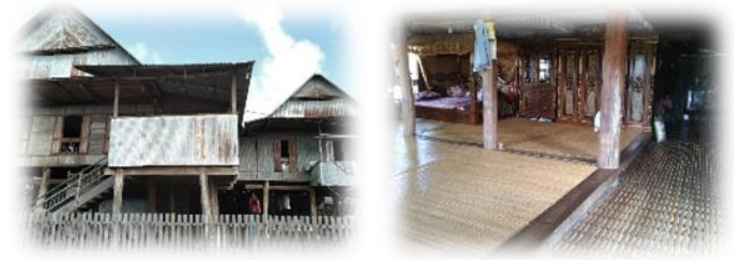

Figure 11. Uwa' Sikki's House

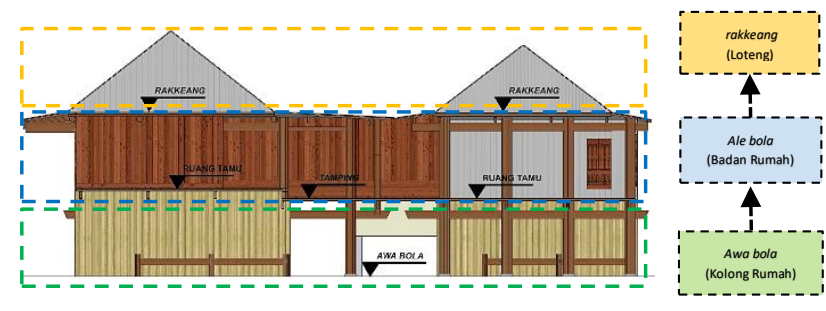

Figure 12. Vertical Relationship Pattern of Uwa' Sikki's House

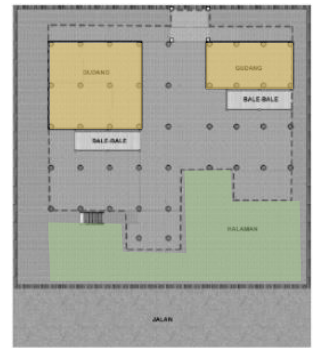

(a)
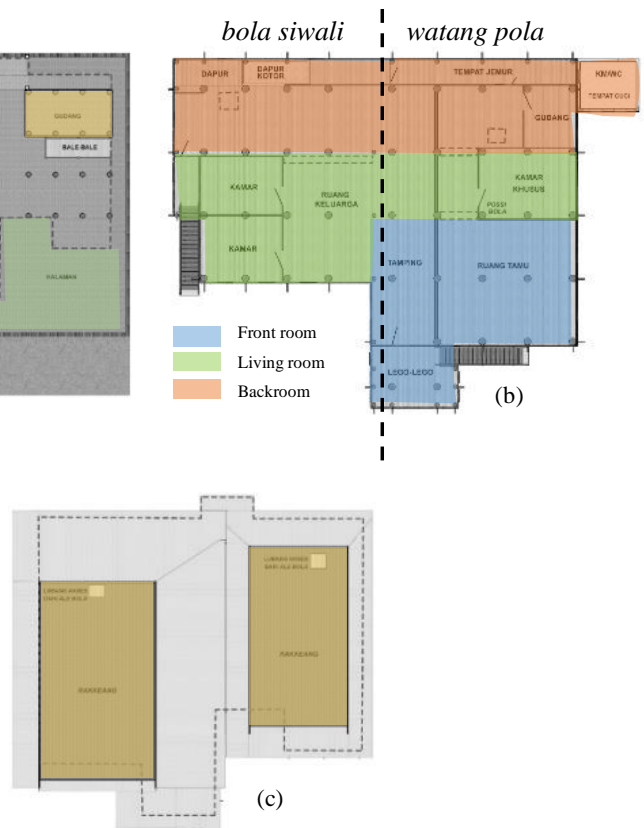

Figure 13. Horizontal Relations Pattern of Uwa' Sikki's House (a) awa bola, (b) ale bola, (c) rakkeang

In Fig. 13 part (a) is the spatial pattern of $U w a$ ' Sikki's house, where there is a yard area marked in green, then underneath the house is a storage room for farming equipment and other tools marked in orange.

Section (b) is zoning and spatial pattern of Uwa' Sikki's house. Uwa' Sikki's house consists of watang pola and bola siwali. In the house there are three zones, the blue one is the front, consisting of lego-lego as a place to wait for guests, living room and tamping, where the position of tamping is lower than the living room is intended as a tribute to the customary holders, because ordinary people can only sit on the tamping. Then the green color is the middle part consisting of a special room as a place of ritual and praying, where the special room is placed right on the possi bola (center of the house), the possi bola is one of the sacred parts of the house, so this room is also considered sacred. Then the red color is the back, consisting of the family room, storeroom, kitchen, bathroom/WC, washing area, and clothesline.

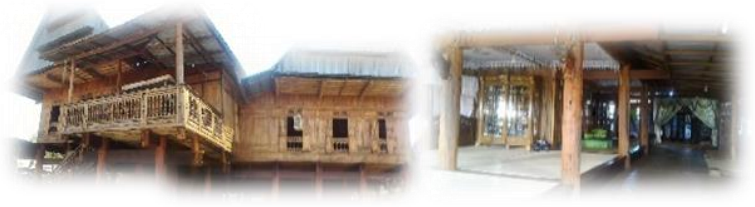

Figure 14. Uwa' Cina's House 


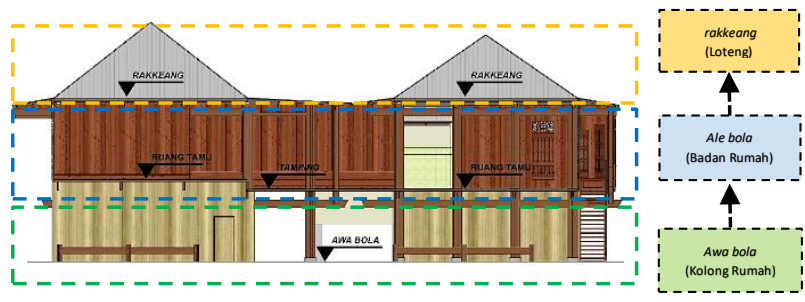

Figure 15. Vertical Relationship Pattern of $U w a$ ' Cina's House

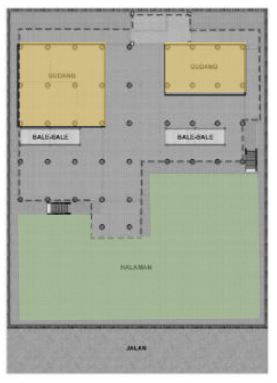

(a)
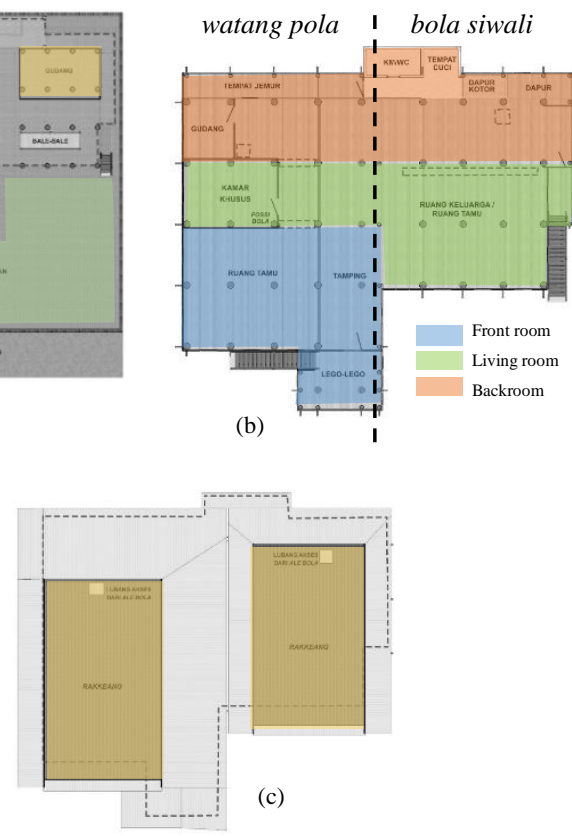

Figure 16. Horizontal Relations Pattern of Uwa' Cina's House (a) awa bola, (b) ale bola, (c) rakkeang

Part (c) is the layout pattern of the rakkeang (attic) of Uwa' Sikki's house which is used to store the harvest. In that house the shelves are marked in orange.

\section{e. Uwa' Cina' (Sample 5)}

Figure 14 is a view and space in the house of $U w a$, Cina'. Figure 15 is the vertical relationship pattern of $U w a$ ' Cina's house, which starts from the awa bola (under the house), then goes to the ale bola (body of the house), then goes up to the rakkeang (attic).

Figure 16 part (a) is the spatial pattern of $U w a$ ' Cina's house, where there is a yard area marked in green, then underneath the house is a storage room for farming equipment and other tools marked in orange.

Part (b) is the zoning and spatial pattern of Uwa' Cina's house. The Uwa' Cina's house consists of watang pola and bola siwali. In the house there are three zones, the first of which is the blue color in the front, consisting of lego-lego as a place to wait for guests, living rooms and tamping, where tamping positions is lower than the living room is intended as a tribute to the customary holder, because ordinary people can only sit on tamping. Then the green color is the middle part consisting of a special room as a place of ritual and praying, where the special room is placed right on the possi bola (center of the house), the possi bola is one of the sacred parts of the house, so this room is also considered sacred. Then the red color is the back, consisting of the family room, storeroom, kitchen, bathroom / WC, washing area, and clothesline.

Part (c) is the layout pattern of the rakkeang (attic) of Uwa' Cina's house which is used to store the harvest. In that house the shelves are marked in orange.

In the five sample images above, it can be seen the spatial pattern in the Towani Tolotang traditional house, vertically all samples have the same pattern because indeed the Towani Tolotang traditional house is a stilt house. The pattern starts from the awa bola (under the house), then goes up to the ale bola (the body of the house), then goes up to the rakkeang (attic).

Horizontally, the spatial pattern of the Towani Tolotang traditional house as a whole from the sample also has the same pattern. Starting from the awa bola (under the house) both in the watang pola and bola siwali there is a yard and a warehouse to store farming equipment.

In the ale section of ale bola or body of the house as a whole of the sample also has the same pattern. In the Watang pola or the main house, starting from the front there are lego-lego as a place to wait before entering the house, then entering the house there is a living room and tamping, then there is a special room right on the possi bola, then at the rear there is a warehouse, buffer, bathroom/toilet and washing area, as well as a clothesline. On the bola siwali or side / additional house consisted of several rooms and family gathering rooms, but there were also those who do not make rooms in the bola siwali, only left empty in order to receive more guests when there are traditional activities. There was a slight difference, in the sample 2 Uwa' Eja's house there was no bola siwali, then in sample $1 U w a$ ' Tadang's house and sample $3 U w a$ ' Jappi house, the bola siwali position is in the south while in sample 4 Uwa' Sikki's house and sample 5 Uwa' Cina's house the bola siwali position was in the north. Although different positions, the spatial pattern of Towani Tolotang's traditional houses from the whole sample remains the same.

At the top of the house there is a rakkeang or attic that is commonly used to store crops, to access it is made a hole in the ceiling of the house. Both watang pola and bola siwali have rakkeang. All of the samples have the same pattern in the watang pola and bola siwali.

Overall, based on observations, direct observations and interviews with customary leader ( $U w a$ '), that all Towani Tolotang's traditional houses have the same house form. There is a slight difference in the location or position of the bola siwali. However, according to Uwa', there are no specific rules or provisions regarding the rotation or direction of the house, everything is adjusted from the site and surrounding environment. Then there is also the Uwa' house 'which does not have a bola siwali because they lack of land to build and also that they live close to other families such as their parents or siblings. For the spatial planning patterns in the Towani Tolotang's traditional house, everything is almost the same. There is a slight difference in the living room, there are some $U w a$ ' houses which do not add rooms to the bola siwali with the reason to get more space when there are traditional activities and invite many guests or families. 


\subsection{Characteristics of Micro spatial patterns, functions} and meanings in the Towani Tolotang's traditional house.

Table 1 presents a characteristics of micro spatial patterns, functions and meanings of the awa bola (underneath) Towani Tolotang's traditional house. In the table there are zoning spaces that indicate the position and nature of space, there are also classifications that indicate the characteristics or specific properties of space. In the table can be seen that there are two spaces as characteristics of the house: yard and farm equipment storage. Then in the table there is a description of the function and meaning of each space.

Table 1. Characteristics of micro spatial patterns, functions and meanings on awa bola (under the house) of Towani Tolotang's traditional house

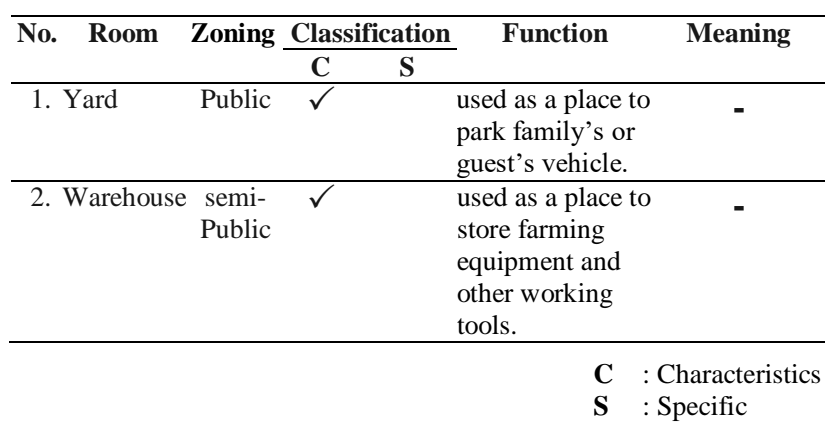

In Table 2 the characteristics of micro spatial patterns, functions and meanings are summarized on the ale ale (house body) of Towani Tolotang's traditional house. In the table there are zoning spaces that indicate the position and nature of space, and there are also classifications that indicate the characteristics or specific properties of space. In the table can be seen that there are nine spaces that become the characteristics: lego-lego, tamping, living room, family room, special room, warehouse, kitchen, bathroom/toilet and washing area and clothesline, then there is one specific room, namely bedroom because there is $U w a$ ' house that does not have a bedroom for his own reasons. In Towani Tolotang's traditional house, there are two spaces as characteristics that have differences with the Bugis's houses in general, tamping and special rooms. Tamping is used as a place to receive regular community guests. There is difference in height between tamping and the living room. Every Towani Tolotang's traditional house also has a special room as a place of ritual and prayers, where the special room is placed right on the possi bola (center of the house), the possi bola is one of the sacred and considered sacred parts of the house, so this room is also considered sacred. Then in the table there is a description of the function and meaning of each space.
Table 2. Characteristics of micro spatial patterns, functions and meanings on ale bola (the body of the house) of Towani Tolotang's traditional house

\begin{tabular}{|c|c|c|c|c|c|}
\hline No. & Room & Zoning & Classification & Function & Meaning \\
\hline & Name & & $\begin{array}{ll}\mathbf{C} & \mathrm{S} \\
\end{array}$ & & \\
\hline 1. & $\begin{array}{l}\text { Lego- } \\
\text { lego }\end{array}$ & $\begin{array}{l}\text { Public } \\
\text { (Front } \\
\text { room) }\end{array}$ & $\checkmark$ & $\begin{array}{l}\text { Places to wait for } \\
\text { guests who will } \\
\text { come to visit or } \\
\text { where guests wait } \\
\text { until the host } \\
\text { comes out to } \\
\text { entertain. }\end{array}$ & $\begin{array}{l}\text { Lego-lego is there } \\
\text { because at the Towani } \\
\text { Tolotang's traditional } \\
\text { house, each new guest } \\
\text { or ordinary } \\
\text { community must get } \\
\text { permission before } \\
\text { entering and not } \\
\text { indiscriminately } \\
\text { entering the house. }\end{array}$ \\
\hline 2. & $\begin{array}{l}\text { Living } \\
\text { room }\end{array}$ & $\begin{array}{l}\text { semi- } \\
\text { Public } \\
\text { (Front } \\
\text { room) }\end{array}$ & $\checkmark$ & $\begin{array}{l}\text { as a room to } \\
\text { receive honored } \\
\text { guests or close } \\
\text { family, } \\
\text { sometimes also } \\
\text { used for tudang } \\
\text { sipulung } \\
\text { activities. }\end{array}$ & $\begin{array}{l}\text { - No chair or table in } \\
\text { the living room means } \\
\text { a sense of } \\
\text { togetherness and } \\
\text { intends to further } \\
\text { kinship. } \\
\text { - The position of the } \\
\text { living room is higher } \\
\text { than tamping to } \\
\text { distinguish the } \\
\text { position of } U w a \text { ' and } \\
\text { its people, meaning } \\
\text { respect for customary } \\
\text { leaders. }\end{array}$ \\
\hline 3. & Tamping & $\begin{array}{l}\text { semi- } \\
\text { Public } \\
\text { (Front } \\
\text { room) }\end{array}$ & $\checkmark$ & $\begin{array}{l}\text { A place to receive } \\
\text { guests with the } \\
\text { status of ordinary } \\
\text { people in the } \\
\text { Towani Tolotang } \\
\text { community. }\end{array}$ & $\begin{array}{l}\text { The position of } \\
\text { tamping is lower than } \\
\text { the living room, } \\
\text { ordinary people can } \\
\text { only sit on tamping, } \\
\text { the behavior of people } \\
\text { on functioning } \\
\text { tamping is a } \\
\text { meaningful symbol as } \\
\text { a people's } \\
\text { appreciation to their } \\
\text { leader }(U w a \text { '). }\end{array}$ \\
\hline 4. & Room & $\begin{array}{c}\text { Privat } \\
\text { (Living } \\
\text { room) }\end{array}$ & $\checkmark$ & $\begin{array}{l}\text { As a room for } \\
\text { resting and } \\
\text { sleeping, it is } \\
\text { usually used for } \\
U w a \text { ' and girls or } \\
\text { children of } U w a \text { ' } \\
\text { who are married } \\
\text { who still live with } \\
\text { their parents. }\end{array}$ & - \\
\hline 5. & $\begin{array}{l}\text { Family } \\
\text { room }\end{array}$ & $\begin{array}{l}\text { semi- } \\
\text { Public } \\
\text { (Living } \\
\text { room) }\end{array}$ & $\sqrt{ }$ & $\begin{array}{l}\text { as a family } \\
\text { gathering room } \\
\text { and also used to } \\
\text { relax. }\end{array}$ & - \\
\hline 6. & $\begin{array}{l}\text { Special } \\
\text { room }\end{array}$ & $\begin{array}{c}\text { Privat } \\
\text { (Living } \\
\text { room) }\end{array}$ & $\sqrt{ }$ & $\begin{array}{l}\text { used as a place of } \\
\text { ritual and pray for } \\
\text { the people of } \\
\text { Towani Tolotang. }\end{array}$ & $\begin{array}{l}\text { special room is placed } \\
\text { right on the possi bola } \\
\text { (center of the house), } \\
\text { possi bola is one part } \\
\text { of the house that is } \\
\text { sacred and considered } \\
\text { sacred, so this room is } \\
\text { also considered } \\
\text { sacred. }\end{array}$ \\
\hline 7. & $\begin{array}{l}\text { Warehou } \\
\text { se }\end{array}$ & $\begin{array}{l}\text { Privat } \\
\text { (Living } \\
\text { room) }\end{array}$ & $\sqrt{ }$ & $\begin{array}{l}\text { used for storing } \\
\text { household goods } \\
\text { and equipment. }\end{array}$ & - \\
\hline 8. & Kitchen & $\begin{array}{c}\text { Service } \\
\text { (Back } \\
\text { room) }\end{array}$ & $\checkmark$ & $\begin{array}{l}\text { used for cooking } \\
\text { activities for } \\
\text { women, but also } \\
\text { a place to store } \\
\text { kitchen } \\
\text { equipment. }\end{array}$ & $\begin{array}{l}\text { the kitchen is always } \\
\text { placed in the back of } \\
\text { the house because it is } \\
\text { privacy and many } \\
\text { activities of woman } \\
\text { are there. }\end{array}$ \\
\hline
\end{tabular}




\begin{tabular}{llll}
\hline 9. $\begin{array}{l}\text { Bathroo } \\
\mathrm{m} \quad / \text { Service } \\
\text { (Back }\end{array}$ & $\checkmark$ & $\begin{array}{l}\text { used for clean-up, } \\
\text { defecate and } \\
\text { shower. There is }\end{array}$ \\
$\begin{array}{l}\text { Washing } \\
\text { area }\end{array}$ & & $\begin{array}{l}\text { room) } \\
\text { also a washing } \\
\text { area on the front } \\
\text { or side, }\end{array}$ & - \\
\hline $\begin{array}{l}\text { Drying } \\
\text { area }\end{array}$ & $\begin{array}{l}\text { Service } \\
\text { (Back } \\
\text { room) }\end{array}$ & $\begin{array}{l}\text { used for drying } \\
\text { clothes or other } \\
\text { equipment. }\end{array}$ & - \\
& &
\end{tabular}

C : Characteristics

S : Specific

Table 3. Characteristics of micro spatial patterns, functions and meanings on rakkeang (attic) of Towani Tolotang's traditional house

\begin{tabular}{|c|c|c|c|c|c|c|}
\hline \multirow[t]{2}{*}{ No. } & \multirow{2}{*}{$\begin{array}{l}\text { Room } \\
\text { Name }\end{array}$} & \multicolumn{3}{|c|}{ Zoning Classification } & \multirow[t]{2}{*}{ Function } & \multirow[t]{2}{*}{ Meaning } \\
\hline & & & $\mathbf{C}$ & $\mathbf{S}$ & & \\
\hline 1. & $\begin{array}{l}\text { Rakkeang } \\
\text { (loteng) }\end{array}$ & Privat & $\checkmark$ & & $\begin{array}{l}\text { used as a place to } \\
\text { store crops such } \\
\text { as rice, corn and } \\
\text { other objects. }\end{array}$ & $\begin{array}{l}\text { Towani } \\
\text { Tolotang's } \\
\text { belief that } \\
\text { rakkeang is } \\
\text { considered as } \\
\text { the world } \\
\text { above or close } \\
\text { to the sky and } \\
\text { the creator so } \\
\text { that it is } \\
\text { considered } \\
\text { sacred. }\end{array}$ \\
\hline
\end{tabular}

C : Characteristics

S : Specific

Table 3 is a characteristics of micro spatial patterns, functions and meanings of the Towani Tolotang's traditional house. In the table there are zoning spaces that indicate the position and nature of space. There are also classifications that indicate the characteristics or specific properties of space. In the table, it can be seen that there is one room being the characteristics, namely rakkeang (attic), a place to store harvests. Then in the table there is a description of the function and meaning of space.

\section{Conclusions and Suggestions}

\subsection{Conclusion}

The first, Towani Tolotang's traditional house is in the form of a stilt house like Bugis's houses in general, so that the vertical spatial pattern of Towani Tolotang's traditional house is vertically started from awa bola (under the house), then goes up to ale bola (home body), then goes up to rakkeang (attic).

The characteristics of the micro spatial pattern of the Towani Tolotang's traditional house horizontally is in the awa bola (under the house). There are two spaces: the house yard and the warehouse. Then in the ale bola (home body) is divided into three parts, namely lontang risaliweng (front room), lontang ritengnga (front room) and lontang rilaleng (back room). In lontang risaliweng (front room) there are three spaces namely lego-lego, tamping, and living room. In Lontang ritengnga (living room) there are three rooms, namely bedroom, family room, and special room, but the bedroom is specific because there are some $U w a$ ' houses that do not use the bedroom for some reasons. In the lontang rilaleng (back room) there are four rooms namely warehouse, kitchen, bathroom/toilet and washing area, as well as a clothesline. Then the very top of the house is a rakkeang (attic). In Towani Tolotang's traditional house there are two spaces as characteristics that make it different from the Bugis's houses in general: Tamping, a place to receive ordinary guests which is different in height with the living room, and the existence of a special room as a place of ritual and pray.

The second matter concerns the function of space in the traditional house of Towani Tolotang. Every room in the Towani Tolotang's traditional house has a general function like the Bugis's houses in general. However, there are two rooms that have a special function in the Towani Tolotang's traditional house, namely the tamping which has a function as a place to receive guests with ordinary community status in the Towani Tolotang community. Then there is a special room that is used as a place of ritual and pray for the people of Towani Tolotang.

The third matter concerns the meaning of space in Towani Tolotang traditional house. In Towani Tolotang traditional house, not all rooms have special meanings, but there are six rooms that have their own meaning related to the spatial planning. Space that has a special meaning, namely; 1) lego-lego, in the Towani Tolotang's traditional house, there are lego-lego where every new guest or ordinary community must get permission and not just enter the house; 2) tamping, tamping position is lower than the living room because ordinary people in the Towani Tolotang community are only allowed to sit in tamping, the behavior of the people on functioning tamping is a meaningful symbol as a people's appreciation to their leader ( $\left.\left.U w a^{\prime}\right) ; 3\right)$ the living room, does not have a chair or table that has a sense of togetherness and intends to establish more kinship; 4) special room, this room is placed right on the possi bola (center of the house), possi bola is one of the sacred parts of the house and is considered sacred, so this room is also considered sacred; 5) kitchen, this space is always placed at the back of the house because it is privacy and there are many activities for women; and 6) rakkeang, the Towani Tolotang community's belief that rakkeang is considered to be the world above or near the sky and the creator so that its nature is considered sacred.

\subsection{Suggestions}

Based on the results of research that has been done, suggestions that can be submitted in this study are as follows:

1. Towani Tolotang's traditional house architecture is the brainchild of the Towani Tolotang community, especially in Amparita which must be preserved as part of regional culture as well as one of the diversity and cultural richness of the Indonesian people.

2. The implied values in the Towani Tolotang traditional house should be used as guidelines to maintain and strengthen solidarity for the Towani Tolotang community. 
In this research, it is undeniable that there are still many shortcomings so it is deemed necessary to be developed further and more in-depth studies on the Towani Tolotang traditional house from other aspects and perspectives that can be carried out.

\section{References}

[1] D. Sumintardja, Kompedium Sejarah Arsitektur, 1st ed. Bandung: LPBM, 1975.

[2] A. Rapoport, House, Form and Culture. New Jersey: Prentice-Hall, Inc., 1969.

[3] Ching and D. K. Francis, Bentuk, Ruang dan Susunannya. Jakarta: Erlangga, 1999.
[4] S. Gunadi, Merencana Ruang Luar. Surabaya: ITS, 1984.

[5] Mangunwijaya, Wastu Citra. Jakarta: PT. Gramedia, 1992.

[6] Feldman and E. Burke, Art as Image and Idea. New Jersey: PrenticeHall, Inc., 1967.

[7] Piliang and Y. Amir, "Pluralitas Bahasa Rupa: Membaca Pemikiran Primadi Tabrani," J. Ilmu Desain, vol. 1, no. 1, 2006.

[8] Moleong and J. Lexy, Metodologi Penelitian Kualitatif. Bandung: PT. Remaja Rosda Karya, 2000.

[9] Wirawan, Evaluasi: Teori, Model, Standar, Aplikasi, dan Profesi, Depok. Pt. Raja Grafindo Persada, 2012.

[10] Sugiyono, Metode Penelitian Kuantitatif, Kualitatif. Bandung: CV. Alfabeta, 2017.

[11] Sutopo, Metodologi Penelitian Kualitatif. Surakarta: UNS, 2006.

[12] Moleong and J. Lexy, Metodologi Penelitian Kualitatif. Bandung: PT. Remaja Rosda Karya, 2007. 